Invest. Pens. Crit.(ISSN 1812-3864; eISSN 2644-4119)

Vol. 10, No. 1, Enero - Abril 2022. pp. 59 -63

DOI: https://doi.org/10.37387/ipc.v10i1.276

Ensayo

\title{
Del animal al hombre: microorganismo emergente: novel coronavirus: Covid 19: de Wuhan hacia el mundo, una pandemia debilitante
}

\section{From animal to man: emerging microorganism: novel coronavirus: Covid 19: from Wuhan to the world, a debilitating pandemic}

\author{
Alexis De La Cruz Lombardo ${ }^{1, *}$, \\ ${ }^{1}$ Docente e investigador del Centro Regional Universitario de Azuero \\ Panamá, Herrera, Chitré, Llano Bonito \\ https://orcid.org/0000-0002-1938-6535
}

* Autor por correspondencia: Alexis De La Cruz Lombardo, alexish2o2@hotmail.com

Recibido: 02 de septiembre de 2021

Aceptado: 22 de noviembre de 2021

\section{Resumen}

A finales del 2019, se reconoció en Wuhan, China un nuevo patógeno viral SARS CoV-19, una nueva cepa de Coronavirus, lo que se declara Pandemia, para el 2020. El alcance y efecto final de esta pandemia no está claro en la actualidad ya que la situación está evolucionando rápidamente. Su rápida transmisión sugiere el modo primario de transmisión de humano a humano. Con más de 144.900 infectados y cerca de 5.400 muertos hasta el 14 de marzo de 2020, el covid-19 se ha expandido a más de 110 países. El impacto de coronavirus es un recordatorio de que el sistema inmune es una serie compleja de defensas de muchas cosas. La trayectoria de esta pandemia es imposible de predecir, la respuesta efectiva requiere una acción rápida desde el punto de vista de las estrategias clásicas de salud pública para el desarrollo oportuno y la implementación de contramedidas efectivas. Las medidas de contención, aislamientos, uso de mascarillas y medidas sanitarias rígidas como lavado de las manos son básicas para detener la propagación del virus.

Palabras clave: Coronavirus; SARS CoV-19; Sistema inmune; Aislamiento.

\begin{abstract}
At the end of 2019, a new viral pathogen SARS CoV-19, a new strain of Coronavirus, was recognized in Wuhan, China, declared a Pandemic by 2020. This pandemic's scope and the ultimate effect are currently unclear as the situation is rapidly evolving. Its rapid transmission suggests the primary mode of human-to-human transmission. With more than 144,900 infected and nearly 5,400 dead as of March 14, 2020, COVID-19 has spread to more than 110 countries. The impact of Coronavirus is a reminder that the immune system is a complex series of defenses of many things. The trajectory of this pandemic is impossible to predict; effective response requires rapid action from the point of view of classical public health strategies for the timely development and implementation of effective countermeasures. Containment measures, isolations, masks, and strict sanitary measures such as hand washing are basic to stop the spread of the virus.
\end{abstract}

Keywords: Coronavirus; SARS CoV-19; Immune system; Isolation 


\section{Introducción}

Los coronavirus son virus de ARN de cadena positiva grandes con tamaños que van de 60 a $220 \mathrm{~nm}$, y envueltos que se pueden dividir en 4 géneros: alfa, beta, delta y gamma, de los cuales se sabe que los CoV alfa y beta infectan a los humanos. Cuatro HCoV (HCoV 229E, NL63, OC43 y HKU1), infectan pájaros y mamíferos, incluyendo al humano, se transmiten por aerosol o la ruta oro fecal, son endémicos en todo el mundo y representan el $10 \%$ al $30 \%$ de las infecciones del tracto respiratorio superior en adultos. Los coronavirus son ecológicamente diversos, con la mayor variedad observada en murciélagos, lo que sugiere que son los reservorios de muchos de estos virus. Los mamíferos peri domésticos pueden servir como hospedadores intermedios, facilitando eventos de replicación. Los coronavirus humanos (HCov) se han considerado patógenos sin consecuencias durante mucho tiempo, causando el resfriado común, en personas sanas. Sin embargo en el siglo XXI, dos $\mathrm{HCoV}$ altamente patógenos, el coronavirus del síndrome respiratorio agudo severo (SARS-CoV) y el coronavirus del síndrome respiratorio del Medio Oriente (MERS-CoV) surgieron de los reservorios animales para causar epidemias globales con morbilidad y mortalidad alarmantes. En diciembre de 2019, se reconoció en Wuhan, China, otro HCoV patógenos, el nuevo coronavirus 2019 (2019.nCoV).

Si bien el MERS no ha causado el pánico internacional que se observó con el SARS, la aparición de este nuevo coronavirus humano zoonotico altamente patógeno ilustra a la amenaza que representa esta familia viral. En el 2017, la Organización Mundial de la Salud (OMS) coloco al SARS-CoV y el MERS-CoV en su lista de patógenos prioritarios, con la esperanza de impulsar la investigación y el desarrollo de contramedidas contra los CoV. En 2012 otro beta-CoV altamente patógeno hizo que la especie saltara cuando se reconoció el síndrome respiratorio del Medio Oriente (MERS) y se identificó el MERS-CoV, en el esputo de un hombre saudí que murió por insuficiencia respiratoria. Mientras que el SARS se extendió rápidamente por todo el mundo y fue contenido y eliminado, en un tiempo relativamente corto, el MERS, se ha caracterizado por una transmisión zoonotica esporádica y cadenas limitadas de propagación humana. el MERS-CoV no ha sostenido la difusión comunitaria, en cambio ha provocado eventos explosivos de transmisión nosocomial, en algunos casos vinculado a un solo superespagador, que son devastadores para los sistemas de salud. Según la OMS, hasta noviembre de 2019, MERS-CoV ha causado un total de 2,494 casos y 858 muertes, la mayoría en Arabia Saudita. Se presume que el reservorio natural de MERS-CoV son murciélagos, aunque los eventos de transmisión humana se han atribuido principalmente a un hospedero intermedio el camello dromedario.

El MERS comparte muchas características clínicas con el SARS, como la neumonía atípica grave, aunque las diferencias claves son evidentes. Los pacientes con MERS tienen síntomas gastrointestinales prominentes y, a menudo, insuficiencia renal aguda, probablemente explicada por la unión de la glicoproteína MERS-CoV a la dipeptidil peptidasa 4 (DPP4), que está presente en la vía aérea inferior, así como el tracto gastrointestinal y el riñón, en el caso del nuevo coronavirus posee una glicoproteína de superficie que es crítica para la unión de los receptores de células del huésped y se cree que representa una determinante clave en la restricción del rango del hospedero. MERS necesita ventilación mecánica en 50\% a 89\% de los pacientes y tiene una tasa de letalidad del 36\%. En el caso de nCoV-2019, la transmisión de persona a persona está documentado, esta propagación puede explicarse por la virológica básica, el receptor humano predominante para la glicoproteínas del SARS, la enzima convertidora de angiotensina humana 2 (ACE2), se encuentra principalmente en el tracto respiratorio inferior, en lugar de en la vía aérea superior. La distribución de los receptores puede explicar tanto la escasez de sintomas del tracto respiratorio superior, como el hallazgo de que la eliminación viral máxima se produjo tarde (10 días). En el caso de complicaciones respiratorias es importante otras pruebas que son previas a las de diagnóstico molecular, tales como examen cardiovascular, pruebas radiográficas pulmonares, prueba de linfocito, proteínas $\mathrm{C}$ reactivas, deshidrogenasa láctica y creatinina.

El 31 de diciembre de 2019, las autoridades chinas informaron un grupo de casos de neumonía en Wuhan, China, el alcance y efecto final de esta pandemia no está claro en la actualidad ya que la situación está evolucionando rápidamente. Su rápida transmisión sugiere el modo primario de transmisión de humano a humano.

Si bien la trayectoria de este brote es imposible de predecir, la respuesta efectiva requiere una acción rápida desde el punto de vista de las estrategias clásicas de salud pública para el desarrollo oportuno y la implementación de contramedidas efectivas.

El impacto de coronavirus es un recordatorio de que el sistema inmune es una serie compleja de defensas de muchas cosas, y la bioquímica de por qué puede ser más eficaz en diferentes fases de la vida y contra diferentes enfermedades, no se comprende completamente.

Muchos virus pueden saltar de una especie a otra con tan solo una mutación puntual un cambio en solo una letra del código genético del viral, a nivel de los hospederos intermediario se amplifica la capacidad genética, 
facilitando eventos de combinación y nutación con expansión de la diversidad genética, eso sucedió en la década de 1990, cuando un virus roedor que gano la capacidad de propagarse fácilmente entre los caballos, causando un tipo de encefalitis equina, en otra ocasión, un cambio aparentemente pequeño en un virus canino condujo a la propagación entre los mapaches, se cree que el sarampión desciende de un virus que infecta a las vacas, la gripe se originó en las aves, aunque tiende a pasar y evolucionar en otros animales, como los cerdos, antes de adquirir la capacidad de virulencia , a los virus no les importa en qué dirección van, pero las máscaras que pueden haber visto en gatos y otras mascotas, los coronavirus pueden infectar a gatos y perros, pero son de la variedad alfa, el nuevo coronavirus humano es de la variedad beta, lo que significa que una proteína clave es lo suficientemente diferente como para que las personas y sus mascotas no puedan transmitir el virus de un lado a otro. Los virus son una parte clave de lo que nos hace humano, dijo Luis P. Villareal, profesor emérito de biología molecular en la Universidad de California (Talavera et al., 2017). Además de los genes, el genoma humano contiene innumerables fragmentos de material genético viral, restos de cuando nuestros antepasados estuvieron expuestos a varios virus en el pasado. Si comparas nuestras secuencias genéticas con algunos de los otros primates, esto es lo que realmente varia, las secuencias genéticas, material parasitario infeccioso, es realmente el motor de la especiación, aun así, los virus pueden causar enfermedades mortales, y a los epidemiólogos les gustaría mucho identificar lo que necesitan para saltar de un animal al otro, para prevenir la próxima epidemia, no es una tarea fácil. En el caso del nuevo coronavirus un cambio genético le permitió la capacidad de adherirse a las células del sistema respiratorio humano, de esa forma el virus se hace más experto en hacer copias de mismo dentro de las células humanas, más aun otra mutación podría mejorar su capacidad de propagarse de humanos a humano como en efecto lo tiene potencialmente, probablemente tales cambios podrían ser más probables en un entorno con múltiples tipos de animales, permitiendo el intercambio total de material genético. Algunas buenas noticias en el frente del coronavirus, es que hasta ahora, no ha matado menores de 10 años, los científicos no están seguros del porqué, una teoría es que cuando se enfrentan a ciertos virus desconocidos, los niños pueden combatirlos porque tienen una capa de defensa robusta llamada sistema inmune innato, consiste en glóbulos blancos llamados macrófagos, que pueden detectar y engullir partículas extrañas en el torrente sanguíneo independientemente de su identidad, los adultos también tienen sistemas inmune innatos, pero contra algunos virus, pueden confiar más en el sistema inmunitario adaptativo: células dirigidas que combaten las infecciones que han aprendido a atacar tipos específicos de virus después de haber estado expuestos a ellos en el pasado, y es así cómo funcionan las vacunas, las vacunas contienen una forma inactiva o muerta del virus, e incluso un fragmento, lo que permite, que el sistema inmune responda con el sistema inmune de memoria.

Los científicos aún no han identificado la fuente del nuevo coronavirus, que ha infectado a más de 70,000 personas y mato casi 1,800 , la mayoría en china. Un candidato probable son los murciélagos, que se sabe que albergan otros virus de la misma familia, como se señaló arriba, los investigadores chinos piensan que puede haber pasado por un intermediario, un animal escamoso llamado pangolín que se usa en la medicina tradicional china, sin embargo existen un futuro prometedor en cuanto al desarrollo de vacunas de ácido nucleico. Los antivirales de amplio espectro, como el remdesivir, un inhibidor de la ARN polimerasa, así como el lopinavir / ritonavir y el interferón beta han demostrado ser prometedores contra el MERS-CoV en modelos animales y se está evaluando su actividad contra 2019-nCoV, también se están aplicando vacunas, que tienen enfoques adaptados utilizados para SARS-CoV o MERS-CoV.

Basándose en la experiencia de brotes zonticos anteriores de $\mathrm{CoV}$, las autoridades de salud pública han iniciado actividades de preparación y respuestas, es así como en Wuhan, las autoridades cerraron y desinfectaron el primer mercado identificado, en los Estados Unidos y en otros varios países han iniciado la inspección de entrada de pasajeros de Wuhan en los principales puertos de entrada., en china, Tailandia, Japón y Corea del Sur identificaron rápidamente los casos relacionados con los viajes, aislando a las personas para recibir más atención, el primer caso relacionado con viajes en los Estados unidos ocurrió el 21 de enero.

Con más de 144.900 infectados y cerca de 5.400 muertos hasta el 14 de marzo de 2020, el covid-19 se ha expandido a más de 110 países.

Aunque aún quedan muchas dudas sobre este nuevo virus que apareció por primera vez en la provincia central de Hubei en China, hacia finales de 2019, se estima que el contagio se produce cuando aspiramos pequeñas gotas expulsadas a través de la tos o el estornudo de una persona infectada.

También cuando entramos en contacto con una superficie contaminada por el virus.

Conocemos también sus síntomas: cansancio, fiebre y tos seca son los principales, pero también algunos pacientes pueden tener dolores, congestión nasal, dolor de garganta y diarrea, según la página informativa de la Organización Mundial de la Salud.

¿Pero qué le hace exactamente el coronavirus a nuestro cuerpo? ¿Cómo lo infecta? ¿Y cómo queda nuestro 
organismo después de superar la enfermedad?

"El coronavirus es principalmente un virus respiratorio", le explica a BBC Mundo William Schaffner, profesor de medicina preventiva y enfermedades infecciosas del Centro Médico de la Universidad Vanderbilt, en Estados Unidos. (OMS-OPS,2021)

Por esta razón, comienza infectando la garganta.

Cuando el virus entra en nuestro cuerpo - ya sea por los ojos, la boca o la nariz — "se sujeta a las células de la mucosa del fondo de la nariz y la garganta",

Gracias a sus proteínas en forma de lanza que sobresalen de la superficie, el coronavirus puede penetrar la membrana de estas células.

"Y una vez dentro de la célula, al igual que los demás virus, comienza a darle la orden de producir más virus". Esta es la forma que tiene el virus de replicarse, ya que al ser un agente infeccioso microscópico acelular, solo puede multiplicarse dentro de las células de otros organismos.

Una vez que las copias están listas, salen de la célula donde se originaron, la destruyen, y comienzan a infectar a otras células.

Cada virus, puede crear entre 10.000 y 100.000 réplicas.

"Cuando esto ocurre, el cuerpo se da cuenta de que el virus está allí y produce una respuesta inflamatoria para tratar de combatirlo", explica Schaffner.

"Por eso es que empezamos a sentir un poco de dolor de garganta y es posible que sintamos la nariz tapada". Recorrido

"El virus se dirige luego hacia los conductos bronquiales (las vías respiratorias que llegan hasta los pulmones) y allí produce una inflamación en las mucosas de estos conductos".

"Esto provoca irritación y por ello empezamos a toser", señala Schaffner.

Mientras esto ocurre, "aumenta la respuesta inflamatoria porque el cuerpo está peleando contra el virus, y, como consecuencia, aparece la fiebre".

En este punto es cuando empezamos a sentirnos mal y perdemos el apetito.

De acuerdo a un análisis de la Organización Mundial de la Salud basado en el estudio de 56.000 pacientes, el $80 \%$ de los infectados desarrollará síntomas leves (fiebre, tos, y en algunos casos neumonía), el 14\% síntomas severos (dificultad para respirar y falta de aire) y un $6 \%$ sufrirá una enfermedad grave (falla pulmonar, choque séptico, fallo orgánico y riesgo de muerte).

La situación puede empeorar si el virus "deja el conducto bronquial y llega a los pulmones, donde provoca una inflamación (neumonía)".

"Si una porción suficiente de tejido pulmonar está afectada, al paciente le resultará más difícil respirar, porque no puede exhalar el 'aire malo' e inhalar el 'bueno"'.

Cuando el cuerpo no puede recibir oxígeno suficiente, el paciente debe ser hospitalizado y posiblemente necesitará que lo conecten a un respirador.

El problema no es solo la infección, sino la forma en que responde nuestro organismo para luchar contra ella, le explica a BBC Mundo Kalpana Sabapathy médica clínica y epidemióloga del equipo de salud global de la Escuela de Higiene y Medicina Tropical en Londres, Reino Unido.

"Para evitar que la infección secuestre a nuestras células, nuestro cuerpo produce sustancias químicas que son bastante agresivas".

En el caso de la neumonía, "crea congestión en los pequeños sacos de aire en la base de nuestros pulmones (alvéolos)".

Estas pequeñas estructuras son las que normalmente se llenan de aire, y a través de sus paredes se produce el intercambio gaseoso por el cual el oxígeno llega a la sangre, y de allí al resto del cuerpo.

"Pero si estos sacos están llenos de infección, combinada con la respuesta de nuestro cuerpo a esa infección, tienen menos capacidad para el aire", señala Sabapathy.

"Y si el cuerpo no recibe suficiente oxígeno esto da lugar a una falla respiratoria, y el corazón, al no recibir suficiente oxígeno a través de la corriente sanguínea, no puede funcionar".

Schaffner compara la respuesta inflamatoria con un conflicto bélico.

"Imagínate que es una guerra. Hay dos ejércitos que pelean entre sí, pero a veces las bombas lastiman a civiles. O pueden caer sobre el hospital, o el museo, pero no sobre el enemigo", afirma.

Es decir, la respuesta puede ser tan potente que acaba dañando el tejido donde se aloja el virus.

Lo llamamos daño colateral. Es lo que puede ocurrir cuando la respuesta inflamatoria es tan vigorosa que se suma al problema de la neumonía (...)".

Esto significa que no hace falta que la infección se traslade a otra parte del cuerpo para que una persona infectada se encuentre en estado crítico. 
Entonces... ¿puede el coronavirus propagarse también por otra parte del cuerpo?

De la nariz al recto

Según le explicó al New York Times Amy Compton-Phillips, directora clínica del Sistema de Salud de Providence, en Estados Unidos, la infección puede propagarse desde la nariz hasta el recto.

Un estudio publicado en marzo en la prestigiosa revista The Lancet no es concluyente, pero también sugiere que el covid-19 "no solo es capaz de provocar neumonía, también podría provocar daños en otros órganos como el corazón, el hígado y los riñones, así como en sistemas corporales como el de la sangre o el sistema inmunitario".

En base a estudios que se han hecho sobre el SARS (síndrome respiratorio agudo grave), "primo" del covid19, "pensamos que puede ir a otras partes del cuerpo", dice Scheffer.

Esto puede explicar en parte porque algunos pacientes infectados han sufrido diarrea y dolores abdominales, problemas que no están directamente vinculados a una infección respiratoria.

Hasta ahora, parece que la tasa de mortalidad de CoVID-19 es menor que la de SARS-CoV y MERS-CoV, sin embargo, el alcance final y los efectos está por verse a futuro.

Los síntomas del nCoV-19 o COVID-19, están: fiebre, tos seca, dificultad para respirar, flema, cansancio y debilidad.

Las medidas de contención, aislamientos, uso de mascarillas y medidas sanitarias rígidas como lavado de las manos son básicas para d detener la propagación del virus.

\section{Bibliografía}

1. Organización Mundial de la Salud, Organización Panamericana de la Salud. Febrero 2021. Informe de Situación COVID 19

2. Sergio Talavera Vargas-Machuca, Ismenia Gamboa Oré, Francia Huamán Dianderas, Ricardo Fujita Alarcón c, María Luisa Fajardo Loo, María Luisa Guevara Gil .2017. Diagnóstico molecular de síndrome de Smith-Magenis por MLPA (Multiplex Ligation-dependent Probe Amplification).

Revista Horizonte Medico. 17(3): 73-78 